Ђура Харди

Универзитет у Новом Саду

Филозофски факултет

Одсек за историју

hardidjura@gmail.com
Оригиналан научни рад

примљено: 24. јул 2014

прихваћено: 1. новембар 2014

\title{
„CASTRUM REGIS BACHIENSIS“ ANNO 1328. ИЛИ ЈЕДАН ПРИЛОГ ПИТАЬУ СТАТУСА БАЧКЕ ТВРЪАВЕ
}

Сажетак: У овом раду аутор настоји да да прилог питању коме је припадала бачка тврђава у средњем веку. Бач је још од раног средњег века био једно од најважнијих утврђених места јужне Паноније. У историографији је уврежено мишљење да је Бач, а са њим и његова тврђава, припадао бачком епископу, односно калочко-бачком надбискупу. Ипак, због оскудице извора и дугог временског периода, питање статуса бачке тврђаве је сложено. Аутор скреће пажњу на то да угарски краљ Карло Роберт у једној својој повељи из 1328. године, односно у њеном препису из 1335. године, недвосмислено говори о Бачу као својој тврђави. На основу овог податка може се претпоставити да је тврђава у време устоличења Анжујаца у Угарској имала статус краљевске тврђаве. То је и време током ког је, врло могуће, и изграђено импозантно бачко утврђење по француском или неком другом западном градитељском узору, како је то својевремено закључио Имре Хенслман.

Кључне речи: Бач, бачка тврђава, Карло Роберт Анжујски (1301-1342), Бачка у XIV веку.

Бач се с правом може сврстати у једну од најлепших, нажалост малобројних преосталих, средњовековних тврђава јужне Паноније. Импозантни остаци средњовековног Бача, омеђени Мостонгом која овај град попут пупчане врпце повезује с Дунавом, достојанствено се уздижу изнад хоризонта плодне равнице. Овај јединствени историјски споменик - с обзиром на поднебље у коме је смештен данас привлачи пажњу тек путника намерника. Зналаца махом, који су се запутили у овај живописни део српског Подунавља с намером да походе „успавану“ твђаву и њену околину богате прошлости. Међутим, у средњем веку Бач је био војни, политички, црквено-културни и економски центар који је врвео од људи и живота. Коначно, име Бача се проширило и на целу област - Бачку - којој је он некад био истинско средиште, а данас је тек један њен кутак.

Сасвим је могуће да је првобитно аварско-словенско утврђење на овом стратешком месту постојало још у раном средњем веку. Наиме, положај Бача на дунавској лесној тераси на реци Мостонги био је врло погодан. Мада фигурира према Дунаву, сам локалитет Бач није плаван, а опет је био окружен водом и 
мочварама Мостонге и Дунава што га је предодредило за природну одбрамбену тачку. Кроз Бач је пролазио копнени пут пратећи леву обалу Дунава. На другој страни преко Мостонге, из Бача се излазило на пловни ток велике реке. ${ }^{1}$ У таквим условима, како закључује Сима Ћирковић, настало је насеље које спада у најстарије и најугледније градове на територији Војводине. ${ }^{2}$ Мада нам није циљ да се упустимо у приказ богате историје средњовековног Бача, о чему постоји више садржајних радова и лексикографских одредница које бисмо могли тек невешто да препричамо, због разумевања наше теме истраживања навешћемо најважније податке везане за историјат овог града. ${ }^{3}$

С настанком угарске средњовековне државе, Бач је у њеним оквирима постао војни и политички центар - средиште жупаније. У изворима постојање жупаније се први пут наводи 70-их година XI века, преко имена бачког жупана Вида (1071), мада историографија сматра да није немогуће да је овдашња жупанија настала још у време првог мађарског краља Светог Стефана (997-1038). ${ }^{4}$ Што се тиче околности у којима је настала Бачка бискупија тј. надбискупија, историчари нису били једногласни у вези са овим догађајем. По једнима ју је основао краљ Свети Ладислав (1077-1095), премештањем црквеног средишта из Калоче у Бач. По другима, њен настанак је везан за угарско освајање Сирмијума 1072. године, када је седиште сирмијског грчког епископа било пресељено у Бач. Овде је, потом, првобитно било седиште православне епископије грчког обреда. Од 1093. године јавља се први помен бачког епископа, тј. архиепископа, а од средине XII века ову титулу преузео је калочки надбискуп коме Бач постаје друга резиденција. Средином XII века Бач је и даље био грчко црквено средиште, али од XIII века долази до латинизације и организовања каптола, за који се везује и настанак институције места с јавном вером која је дала посебан допринос бројним поменима Бача у документима. 5 Поред војнополитичког и црквеног средишта, током прве половине XII века Бач израста и у важан трговачки центар. О томе упечатљиво говоре арапски и византијски писци Идризи (1154) и Јован Кинам (1164) који су имали прилику да

\footnotetext{
* Текст је настао као фазни резултат рада на пројекту Војвођански простор у контексту европске историје (број 177002) Министарства просвете, науке и технолошког развоја Републике Србије.

${ }^{1}$ Упор. Бранислав Букуров, Насеља Војводине, у: Војводина знаменитости и лепоте, уредник Михаило Милетић, Београд 1968, 117.

${ }^{2}$ Сима Ћирковић, Бач, у: Војводина знаменитости и лепоте, уредник Михаило Малетић, Београд 1968 , $436-437$.

${ }^{3}$ Најобимнија археолошко-историографска студија о Бачу је написана још у XIX веку: Imre Henszlmann, Bács, Archaeologiai Értesítő, 1870 III kötet, 309-314; IV kötet, 2-9, 24-31, 49-56, 85-93; затим: Rudolf R. Schmidt, Iz prošlosti Bača, Гласник Историјског друштва у Новом Саду, 37-38 (3-4), 1939, 382-413; György Györffy, Az Árpád-kori Magyarország történeti földrajza, I, Budapest 1963, 210-213; С. Ћирковић, Бач, 436-437; Ante Sekulić, Drevni Bač, Split 1978; Ernő Marosi- Miklós Takákacs, Bács, y: Korai magyar történeti lexikon (9-14. század), föszerkesztö Kristó Gyula (даље: KMTL), Budapest 1994, 73-75.

${ }^{4}$ Извори за хронологију настанка Бачке жупаније код: Attila Zsoldos, Magyarország világi archontológiája 1000-1301, Budapest 2011, 125; Упор. С. Ћирковић, Бач, 436; E. Marosi - M. Takákacs, Bács, 73.

${ }^{5}$ E. Marosi - M. Takákacs, Bács, 73; Gy. Györffy, Magyarország történeti földrajza, I, 212. Упор. везано за ову тему садржајан рад о местима писмености на тлу Војводине у средњем веку: Тибор Алмаши, Главне институције писмености места с јавном вером у средњем веку на тлу данашье Војводине, у: Средњовековна насеља на тлу Војводине, историјски процеси и догађаји, уредник Ђура Харди, Сремска Митровица 2013, 29-46.
} 
посете ово богато и напредно место. ${ }^{6}$ Њихови извештаји су незаобилазно навођена места у историографији.

Што се тиче бачке тврђаве, њен први помен, како је утврдио Ђерђ Ђерфи, датира релативно касно, из 1193 (t. piscatorum Bachiensis castri.; земља рибара бачке тврђаве), што дакако не значи да тврђаве у Бачу није било много раније. ${ }^{8}$ Бач, тврђаву и целу област опустошили су Монголи 1241. године након чега је следио успорени опоравак. Током успона Угарске за владавине династије Анжујаца у XIV веку, како је на основу својих археолошких истраживања закључио археолог и историчар Имре Хенслман (Henszlmann, Imre), на месту некадашње старе жупанијске тврђаве била је подигнута нова моћна тврђава од црвене цигле, изгледа, под утицајем француских градитељских узора. ${ }^{9}$ Независно од Хенслмана о могућим француским узорима коришћеним приликом изградње ове тврђаве говори и Ђурђе Бошковић. ${ }^{10}$ Њени импозантни остаци, упркос бројним разарањима у будућим ратовима који ће у међувремену протутњати Панонијом, стоје пред нама и ове 2014. године.

Средњовековни Бач је дакле био средиште истоимене жупаније и једна од две резиденције Калочке надбискупије. Поставља се међутим питање коме је припадала бачка тврђава у средњем веку, краљевском службенику (жупану, тј. краљевском кастелану) или утицајном црквеном прелату, без обзира на околност да су надбискупи понекад истовремено заузимали и место бачког жупана, или пак да је Бачка жупанија као хонор била додељивана мачванском бану. ${ }^{11}$ У историографији је скоро уврежено мишљење да је бачка тврђава током средњег века била посед бачког, тј. калочког надбискупа. На пример, од ове премисе своје истраживање прошлости Бача започео је већ Имре Хенслман. Његов став потом су преузели Деже Чанки ${ }^{12}$ и Рудолф Шмит ${ }^{13}$. И Анте Секулић се слаже да је тврђава припадала надбискупу. ${ }^{14}$ Такође је и студиозни Енгел Пал у својој архонтологији констатовао да је бачка

\footnotetext{
${ }^{6}$ Ján Paulini, Arabské správi o Slovanoch (9.-12. storočie), Bratislava 1999, 147-149; Ioannis Cinnami Epitome rerum ab Ioanne et Alexio Comnenis gestarum, Corpus scriptorum historiae Byzantinae, ed. A. Meineke, Bonae 1836, 222; Упор. и: Gy. Györffy, Magyarország történeti földrajza, I, 210.

${ }^{7}$ Анализа Идризијевог и Кинамовог извештаја о Бачу, односно српском Подунављу, присутна је у радовима Гавре Шкриванића, Симе Ћирковића, Јованке Калић, Петра Рокаија, Бориса Недкова, Тадеуша Левицког (Tadeusz Lewicki), Иштвана Елтера (István Elter) и многих других историчара. Од новијих прилога, библиографски преглед упор. код: Борис Стојковски, Арапски географ Идризи о јужној Угарској и Србији, Зборник Матице српске за историју, 79-80, 2009, 59-60; Александар Крстић, Ковин, у: Лексикон градова и тргова средњовековних српских земаља, редактор Синиша Мишић, Београд 2010, 134.

${ }_{8}^{8}$ Приказ необјављеног извора и анализа његове хронологије код Gy. Györffy, Magyarország történeti földrajza, I, 210, 212.

${ }^{9}$ I. Henszlmann, Bács, Arch. Értesítő, III, 309-313.

${ }^{10}$ Приликом разматрања архитектонске основе (анжујског) Бача, Ђурђе Бошковић је сматрао да би се она донекле могла упоредити са познатом француском тврђавом Кус (Сoucy) у Пикардији (déparmtement Aisne). Вид.: Ђурђе Бошковић, Средњовековни градови у Војводини, архитектура, у: Војводина I, уредник Душан Ј. Поповић, Нови Сад 1939, 329 (напомена 66).

${ }_{11}$ Упор. A. Zsoldos, Archontológia, 125-128; Pál Engel, Magyarország világi archontológiája, I, Budapest 1996, 100-101.

${ }^{12}$ Dezső Csánki, Magyarország történelmi földrajza a Hunyadiak korában, I-III, Budapest 1890-1913, II, 156.

${ }_{13}$ Рудолф Р. Шмит, Средњовековни градови у Војводини, историја, у: Војводина I, уредник Душан J. Поповић, Нови Сад 1939, 308; упор. и: R. Schmidt, Iz prošlosti Bača, 384-388.

${ }^{14}$ Ante Sekulić, Drevni Bač, Split 1978, 28.
} 
тврђава припадала калочком надбискупу, и да се помиње као castrum од 1435. године $(!) .^{15}$

Али о ипак сложеном питању статуса тврђаве интересантну расправу је започео већ учени Хенслман. Он је, наиме, током свог археолошког и историографског истраживања Бача дошао до открића да су бачку тврђаву саградили у XIV веку анжујски владари Угарске. На тај закључак су га навеле две важне чињенице. Проучавајући тврђаву подигнуту од црвене цигле као архитектонску целину са, на пример, карактеристичном готичком капелом на једној од њених кула, он је закључио да је фортификација представљала типичан стил француске градитељске школе XIV века. На другом месту, присутност државног грба на једном од прозора средишње куле га је још више упућивала на претпоставку да је градња била подухват изведен не од стране цркве, већ по краљевом налогу и о његовом трошку који никако није могао бити мали. С обзиром на то да је калочко-бачка надбискупска столица била (како је сматрао) упражњена између 1338. и 1342. године, Хенслман је даље изнео претпоставку да је тврђаву управо тих година могао подигнути тадашњи угарски краљ Карло Роберт (1301-1342) који је искористио околност да управља Бачом. Због чега је црква негодовала као и увек када би владари зарад уживања богатих црквених добара одлагали постављење бискупа? Приказани Хенслманови ставови су имали значајног утицаја на историчаре који су даље писали о Бачу. Хенслман је међутим, поред реченог закључка, у продужетку свог излагања изрекао можда и кључне речи за нашу расправу. Констатовао је да он нажалост не располаже са довољно извора који би потврдили да се у XIV веку тврђава налазила у поседу надбискупа као што је то било у потоњем времену. Краљевски грб га је више упућивао на то да се она налазила у рукама краља, али опет из каснијих извора се јасно видело да је Бач био у власништву калочко-бачког надбискупа (Петера Варадија, 1491). ${ }^{16}$ Хенслмановог мишљења држали су се и Иштван Ивањи и Ференц Фиртер сматрајући да је Карло Роберт упркос околности да је Бач био посед надбискупа, искористио упражњеност црквене столице да би „у своју корист“" изградио нову тврђаву која је требало да му послужи као упориште против српског краља. ${ }^{17}$

Због стања расположивих извора одговор на питање о формалном власништву над бачком тврђавом није лако дати. Коначно, реч је о дугом периоду од XI/XII до почетка XVI века са бројним вишедеценијским празнинама у погледу вести које би говориле о непосредним господарима важне тврђаве, као и евентуалним изворима који чекају да буду интерпретирани. У међувремену, историчари попут Пала Енгела су дошли до нових вредних открића која у сваком случају коригују старија сазнања, на пример, да је калочко-бачка црквена столица била in continuo упражњена седам година, од марта 1337 , до маја 1343 . године. ${ }^{18}$

\footnotetext{
${ }^{15}$ P. Engel, Archontológia, I, 100, 270.

${ }^{16}$ I. Henszlmann, Bács, III k, 309-314.

${ }^{17}$ István Iványi - (Ferencz Virter), Bács-Bodrog vármegye községei, kiegészítette Virter Ferencz, y: Bács-Bodrog vármegye, (ed.) Borovszky Samu, elektronikus kiadás, Budapest Arcanum Adatbázis Kft. 2004 (такође и http://mek.oszk.hu/09500/09536/html/0002/6.html).

${ }^{18}$ Упор. Р. Engel Archontológia, I, 65.
} 
Могуће не случајно, Ђерђ Ђерфи који је без сумње дао најкомплетнији преглед извора о Бачу као и фактографски преглед његове прошлости, о могућим власницима града не говори. ${ }^{19}$ Ни Ерне Мароши и Миклош Такач се у својој лексикографској одредници о Бачу непосредно не изјашњавају коме је бачка тврђава припадала. Ипак, због непостојања извора и самог историјског контекста они доводе у питање Хенслманову претпоставку о краљевском пореклу изградње тврђаве, што их сврстава на страну мишљења по коме је калочки архиепископ био господар „castrum Bachiensis“. ${ }^{20}$

Доиста, ако изузмемо жупанство војсковође краља Матије Корвина, славног борца против Турака Пала Кињижија (Kinizsi Pál) ${ }^{21}$, између 1484. и 1494. године, Бач и с њим цела Бачка жупанија се током скоро целе друге половине XV века налазе у поседу (бачко-)калочких надбискупа. Међу њима најпознатији је био Петер Варади (или Вардаи; Váradi, Várdai, Péter), (као бачки жупан 1480-1484, и други пут 1491-1501, после ослобађања из сужањства у ком га је држао његов неповерљиви господар Матија Корвин). ${ }^{22}$ Овај чувени хуманиста, књижевник, државник и војсковођа је од Бача начинио своје главно средиште у коме је радо боравио. ${ }^{23}$ Надбискупу је у то доба припадала читава варош и њени приходи. ${ }^{24}$ Ова финансијска околност свакако је била предуслов за остварење Варадијевих великих планова. Наиме, ако оставимо по страни познати податак да је у Бачу сместио своју богату библиотеку с латинским, италијанским и грчким књигама, захваљујући његовој градитељској делатности, предузетој у доба опште турске опасности и смутње, некадашње анжујско утврђење је добило нов изглед.

За само два лета, између 1495. и 1497. године, Петер Варади је око Бача изградио широке шанчеве који су омогућавали безбедан смештај велике војске. Такође је прокопао канал, продубивши корито Мостонге, којим је повезао бачку тврђаву са Дунавом. Тврђава је на тај начин била са свих страна опасана дубоком водом што је знатно повећало њену одбрамбену моћ. Овим великим подухватом цело подручје Бача је добило нове обрисе. Канал је био плован, чиме је побољшана веза града с Дунавом и унапређена трговина, док су радови допринели исушивању оближњих мочвара. „На месту мочваре сада тече чиста дунавска вода богата рибом“ - хвалио се својим постигнућем бачки надбискуп у једном писму упућеном његовом сабрату, вацком бискупу, 1497. године. ${ }^{25}$ Пишући из Бача деведесетих година своје

\footnotetext{
${ }^{19}$ Gy. Györffy, Magyarország történeti földrajza, I, 212-213.

${ }^{20}$ E. Marosi - M. Takákacs, Bács, 73.

21 Пал, односно Павле Кињижи, уједно је био и тамишки жупан и Матијин капетан јужне Угарске. Историјска личност добро позната у српској историографији. Упор. детаљније библиографију у: Историја српског народа, група аутора, уредник Јованка Калић, друга књига, Београд 1982, 385-387, 433, 449-452, 458.

${ }^{22}$ Упор. Reiszig Ede, Bács-Bodrog vármegye története, y: Magyarország vármegyéi és városai: Bács-Bodrog vármegye II. Szerk. Borovszky Samu, elektronikus kiadás, Budapest, Arcanum Adatbázis Kft. 2004 (такође и http://mek.oszk.hu/09500/09536/html/0003/4.html).

${ }^{23}$ О личности Петера Варадија: Vilmos Fraknói, Váradi Péter kalocsai érsek élete 1480-1511, Századok 1883 , 489-514, 729-749, 852-843.

${ }^{24}$ С. Ћирковић, Бач, 437.

${ }^{25}$ V. Fraknói, Váradi Péter, 833-834; Упор. Petri de Warda, Epistolae Cum Nonnullis Wladislai II. Regis Hungariae Literis Petri Causa Scriptis, ed. Carolus Wagner, Posonii et Cassoviae 1776, 75, односно 74-76;
} 
чувене epistolae, мислима разапет између својих италијанских хуманистичких узора и турских војних упада, Петер Варади их је завршавао са карактеристичним речима „ex Castro nostro Bachiensi“, или „ех Castro mеo“. ${ }^{26}$ Пред крај XV века, тврђава Бач ce, без икакве сумње, налазила у власништву надбискупа.

Међутим, стање власништва над бачком тврђавом с краја, или из друге половине XV века, ипак је немогуће по аналогији пресликати на ранији период. У том погледу склони смо стати на страну наших опрезних претходника, истраживача бачке прошлости. У прилог овом ставу, уверава нас садржај једне повеље Карла Роберта из 1335, односно 1328. године, чија обавештења ће представљати средишњу тачку овог рада. С намером да потврдимо тезу по којој је бачка тврђава током средњег века ипак мењала своје формалне господаре и да је питање њеног власништва у најмању руку сложено. Односно, да је Бач у време устоличења Анжујаца у Угарској имао статус краљевске тврђаве.

Карло Роберт (односно, његова канцеларија) је 2. новембра 1335. године, због потребе да све раније донационе повеље буду потврђене новим краљевским печатом, преписао даровницу коју је 21. априла 1328. године издао свом присталици и саборцу, врло утицајном барону, краљичином рођаку, ердељском војводи Тамашу Сечењију (Szécsényi Tamás) из рода Качић, ${ }^{27}$ на име два поседа „Kethlugas“ у Бачкој жупанији. Том приликом у препис су поред краљевске даровнице уврштене и повеље које су се, како је правни поступак налагао, односиле на обилазак дариваног поседа и саме потврде увођења у посед, будући да је са његовим границама у погледу сагласности суседа све било у реду. ${ }^{28}$ За нашу тему кључна је сама даровница у којој ауктор саопштава да реченом верном племићу дарује следеће поседе, ,једну земљу наше бачке тврђаве (unam terram castri nostri Bachiensis), и другу, која је присвојена због смрти њеног претходног власника без наследника, зване 'Kethlugas' у Бачкој жупанији““ ${ }^{29}$

Што се историчара тиче, захваљујући исправи сремског каптола у Баноштору (capitulum ecclesie de Kw) сачињеној приликом њихове реамбулације, убикација ових поседа је извесна. ${ }^{30}$ Како открива само њихово име, реч је била о „два луга“ (Két-Lugas) која су се налазила, један до другог, недалеко од Бача, могуће у данашњем атару Обровца. ${ }^{31}$ Владар је дакле два „Луга(ш-а)“ поклонио ердељском војводи, док је заправо, у њиховом суседству, постојао и онај трећи (similiter Lugas

\footnotetext{
Упор. R. Schmidt, Iz prošlosti Bača, 386-388.

${ }^{26}$ Petri de Warda, Epistolae, 34, 36, 45, 48, 52, и даље.

${ }^{27}$ О Тамашу Сечењију у новијој литератури: Ferenc Sebők, Szécsényi, y: KMTL, 620; Monika Skalská, Tomáš zo Sečian a jeho zásluhy v bitke pri Rozhanovciach, y: Bitka pri Rozhanovciach v kontexte slovenských a uhorských dejín. Zborník príspevkov z medzinárodnej vedeckej konferencie pri príležitosti 700. výročia bitky pri Rozhanovciach. Eds. Ferdinand Uličný, Drahoslav Magdoško, Košice 2012, 155-166.

${ }^{28}$ Imre Nagy - Gyula Tasnádi Nagy, Anjoukori okmánytár, Codex diplomaticus Hungaricus Andegavensis I-VII, Budapest 1878-1920 (даље: A), III, 207-210.

${ }^{29}$, ,...quasdam possessiones unam videlicet terrani castri nostri Bachiensis et aliam asserendo fuisse hominis sine herede decedentis Kethlugas vocatas in comitatu Bacliiensi existentes..."A, III, 207.

${ }_{30}$ За места јавне вере Сремске бискупије упор. Т. Алмаши, Главне институције писмености, 40.

${ }^{31}$ О положају три Лугаша: Gy. Györffy, Az Árpád-kori Magyarország történeti földrajza, I, 226-227; Dezső Csánki, Magyarország történelmi földrajza a Hunyadiak korában, II, 156; István Iványi, Bács-Bodrog vármegye földrajzi és történelmi helynévtára, I-V, Szabadka, 1889-1907, III, 72.
} 
vocate) који се налазио у власништву неког „Joannis dicti Turs“-а. ${ }^{32}$

Од два даривана поседа, први је био власништво краљевске тврђаве Бач. Из овог лаконског помена сазнајемо драгоцену вест да је 1328, а по свему судећи и 1335. године, ${ }^{33}$ Бач био краљевска тврђава и посед. ${ }^{34}$ Други „Лугаш“ је био посед извесног „мегданџије“ Петра, који је умро без наследника. ${ }^{35}$ У таквим приликама, правна пракса је била недвојбена. Посед који је по смрти господара остао без мушких наследника био би враћен краљу, као првобитном власнику и дародавцу, с тим да је женским наследницима умрлог, тј. његовим ћеркама ако их је било, из поседа накнадно био издвојен један његов део, такозвана женска четвртина (quarta filiae). У спровођењу овог уобичајеног поступка налази се и објашњење на који је начин Тамаш Сечењи, и заправо и када, дошао у посед добра „Kethlugas“.

Краљ би формално доиста постао власник свих оваквих упражњених поседа али у пракси, поготово ако је реч била о просечним добрима у провинцији за које краљевски двор нити је могао знати где се налазе нити је показивао непосредан интерес за њихово преузимање, они су доспевали у руке њихових најутицајнијих службеника и заступника државне власти у тој области, најчешће жупана, бана или војводе. Дакако, ако је реч била о великој господи која је поред бројних жупанских власти имала и статус дворских великодостојника, а такав је био угледни Тамаш, они би, слично поступку самог владара, исте те поседе затим препуштали, дакако само на коришћење, својим верним фамилијарима, судијама или кастеланима који су у њихово име вршили власт у тој жупанији и потицали из реда локалног племства. Након извесног времена, иста господа би на двору издејствовала да им владар у виду даровнице додели те поседе, или у случају да су били незаинтересовани за њих, да их дарује неком њиховом човеку. ${ }^{36}$ У нашем случају истоветан след догађаја се збио и са поседом „Kethlugas“. Када?

\footnotetext{
${ }^{32}$ A, III, 208.

${ }_{33}$ Додуше, неки скептичан истраживач би могао да устврди да ако је Бач 1328. године био „сastrum regis“, то не значи да је исти статус тврђава нужно имала и 1335. године, јер је документ из 1335 . године садржао само препис повеље која је приказивала стање ствари седам година раније. Ипак, такве сумње треба примити с великом резервом. О евентуалној промени власништва бачке тврђаве нема ни трага у препису, а њега је сачинила краљевска канцеларија у време када је краљев канцелар био калочки и бачки надбискуп.

${ }^{34}$ Овај помен бележи у својој историјској географији, како смо већ рекли без коментара, Ђерђ Ђерфи захваљујући коме смо га и уочили. Код Ђерфија који је пред собом сем публиковане повеље (А, III, 207-210) имао и њен оригинал (према аутору: Magyar Országos Levéltár, Budapest, Mohács etőtti gyüjtemény, Collectio Antemohacsiana, 2499) помен Бача се наводи у облику - „...t. castri nostri [regis] Bachyensis...“. Gy. Györffy, Az Árpád-kori Magyarország történeti földrajza, I, 212.

35 ,...unam [possessionem] terre castri Bachiensis et aliam Petri pugilis hominis quondam sine herede decendentis in ipso comitatu Bachiensi existencium...“ А, III, 208. О „пугилусу Петру“, пре свега његовом несвакидашњем позиву професионалног судског мегданџије као живописном сведочанству о социјалној и професионалној структури житеља Бачке првих деценија XIV века, врло могуће краљевском службенику или службенику Бачке цркве, вредело би, једном другом приликом, написати кратак прилог. Као лични подсетник за остварење ове идеје, име мегданџије Петра смештамо у ову напомену.

${ }^{36}$ Излагање о упражњеним поседима и функционисању хијерархије власти у средњовековној Угарској током прве половине XIV века изводимо на основу нашег проучавања историје једне друге великашке породице анжујског доба, породице Другет, чији су чланови били угарски палатини. Упор. аналогију и преглед релевантне литературе у нашем раду: Đura Hardi, Drugeti, povest o usponu i padu porodice pratilaca Anžujskih kraljeva, Novi Sad, 2012, 168, 285.
} 
На основу реченог, одговор на ово питање се намеће сам по себи - у време када је Тамаш Сечењи био бачки жупан. На челу жупаније Бач Тамаш је стајао од 1318. до 1321. године. ${ }^{37}$ Уједно је био и арадски (1319-1342) и сремски (1319-1321) жупан и краљичин магистар таверника. ${ }^{38}$ По свему судећи, у наведеном периоду је један посед „Kethlugas“, након што се без наследника упокојио његов господар „pugilus Peter“, у име краља доспео под власт бачког жупана Тамаша. За нашу расправу кључно је међутим питање када је други посед „Kethlugas“, онај који је припадао „краљевској тврђави Бач“, доспео у руке истог великаша. Мада не располажемо непосредним изворима, чини нам се више него логичним да су два поседа „Kethlugas“ у исто време прешла под управу ондашњег бачког жупана, а да је даровница из 1328. године била чин санкционисања постојећег стања. Ако би ова претпоставка била тачна, онда би и сама тврђава Бач не само 1328, већ вероватно и између 1318. и 1321. године, припадала краљу. На крају, уздајући се у краљеву милост, предузимљиви Тамаш Сечењи је за време свог кратког службовања у Бачкој постао један од двојице овдашњих најбогатијих поседника. ${ }^{39}$

Познато је да је Карло Роберт своју владавину у Угарској започео управо у јужним областима краљевства. Током прве деценије XIV века, Анжујац је пре био тек један од претендената на краљевску круну изумрлих Арпадовића неголи стварни владар земље. У то време свој двор је сместио у цистерцитској опатији у Петроварадину, живећи под заштитом великаша Угрина Чака који је био бачки, сремски, вуковски и пожешки жупан. Другим речима, неприкосновени господар ових области и њихових тврђава. ${ }^{40}$ Током друге деценије XIV века положај Карла Роберта се побољшао. Будући да су други краљевски претенденти одустали од активне борбе за престо, он је био признат за јединог и законитог краља и сада му је предстојала борба против непокорних угарских великаша који су заправо били стварни владари земље. У међувремену, 1311. године, умро је његов некадашњи заштитник и присталица Угрин. Током општег рата против такозваних олигарха, Карло Роберт је настојао да, тамо где може, на чело тврђава и жупанија постави своје људе. Управо је Тамаш Сечењи добио задатак да у краљево име, 1318. године, преузме и утврди власт и у некадашњим Угриновим жупанијама Бач и Срем. Независно од околности да ли је у њој у исто време своје седиште имао калочки надбискуп, бачка тврђава је вероватно у то доба била једно од најважнијих краљевских упоришта на југу државе због ратова које је Анжујац управо тих година водио против моћне породице Кисеги, господара Прекодунавских области, и још моћнијег и опаснијег јужног суседа, српског краља Уроша Милутина. ${ }^{41}$ Није нам

\footnotetext{
${ }^{37}$ Pál Engel, Magyarország világi archontológiája, I, Budapest 1996, 100.

${ }^{38}$ Исто, 54, 97, 199.

${ }^{39}$ Gy. Györffy, Magyarország történeti földrajza, I, 206. Стицање богатства на овим просторима, некада, изгледа и сада, као да се по неписаном правилу увек одвијало напречац и било повезано с блискошћу појединца с владама и владарима.

40 Детаљније о боравку Карла Роберта на тлу јужне Угарске: Ђура Харди, Петроварадин - „престонииа“” једног Анжујца, у: Средњовековна насеља на тлу Војводине, историјски процеси и догађаји, уредник Ђура Харди, Сремска Митровица 2013, 243-279.

${ }_{41}$ О борбама Карла Роберта против олигарха, детаљније: Pál Engel, Az ország újraegyesitése, I. Károly küzdelmei az oligarchák ellen (1310-1323), Századok, 1988, 89-146.
} 
остало познато да ли је Тамаш Сечењи икада боравио у Бачу или су га овде, док се он налазио у краљевој пратњи, заступали његови фамилијари. Већ 1321. године Тамаш је постао ердељски војвода, а Бачка жупанија је као хонор (награда за службу) прешла под власт других барона. Оно што се мора приметити је да су и они, попут Сечењија, били врло утицајни сарадници Карла Роберта, између 1321. и 1329. године, жупан Бачке је био творац анжујских финансијских реформи, краљевски магистер таверника Деметер Некчеи (Nekcsei Demeter), а потом, између 1330. и 1333, угарски палатин, Жан Другет (Johannes Jean Drugeth). Након ових великаша Бачка жупанија је за дуги низ деценија постала хонор мачванских банова. ${ }^{42}$ Посебно су чланови племићке породице Другет, „Гали“ и напуљски поданици и пратиоци анжујске династије имали великог утицаја на владарску делатност Карла Роберта. ${ }^{43}$

У историографији је, већ смо рекли, општеприхваћена Хенслманова претпоставка да је бачка тврђава подигнута у време Анжујаца, за владавине Карла Роберта или евентуално његовог наследика Лајоша. Као и у случају градње сваке средњовековне тврђаве, по среди је био велики градитељски подухват који је могао трајати годинама и деценијама. Сасвим је могуће да се градња анжујске тврђаве Бач одвијала управо у време док су Бачком жупанијом управљали тројица поменутих барона из круга најближих сарадника Карла Роберта. Учени Деметер Некчеи се по свему судећи школовао на једном од италијанских универзитета, ${ }^{44}$ док је палатин Жан Другет у Угарску стигао из Париза, са ондашњег владарског двора. ${ }^{45}$ Ови барони богатог животног искуства могли су бити прави посредници између ангажовања мајстора који су ову равничарску тврђаву градили по француском или већ неком другом западном градитељском узору и жеља свог господара Карла Роберта. Нажалост, у недостатку писаних извора, одговор када и по нацртима чије градитељске школе је подигнут Бач вероватно ће дати нека будућа археолошка истраживања овог импозантног панонског средњовековног споменика.

Што се тиче судбине поседа „Kethlugas“, она је вредна помена у мери у којој стоји у вези са свом сложеношћу теме нашег истраживања. Тамаш Сечењи је, наиме, „изгубивши интерес“ за ове области, цео низ својих поседа (15, иако махом пустара), стечених претходних година у Бачкој и Сремској жупанији, заменио са калочким надбискупом Ласлом (Ладиславом) Јанкијем (Jánki Lászlo) (1317-1336), за његове поседе у жупанијама Гемер и Кишхонт. Међу поседима који су били предмет замене, коју је краљ одобрио у повељи издатој 24. јуна 1334. године, налазили су се и „Lugas“ и „alia Lugas“. ${ }^{46}$ По свему судећи, бачка црква и њен првосвештеник нису губили интересовање за поседе који су окруживали Бач. Да ли је то подразумевало да је надбискуп поседовао своју резиденцију у Бачу - граду који је истовремено имао статус краљевске тврђаве? Оваква могућност, признајемо, није уопште искључена, мада је не можемо потврдити изворима, као иначе ни непосредно присуство краљевих барона и овдашњих жупана у бачкој тврђави. Сви су они пре

\footnotetext{
${ }^{42}$ P. Engel, Magyarország világi archontológiája, I, 11, 100-101.

${ }^{43}$ О Другетима и њиховом утицају на Карла Роберта детаљно смо писали у: Đ. Hardi, Drugeti.

${ }^{44}$ О личности Деметра Некчеија: Antal Pór, Lipóczi és Nekcsei Demeter és Sándor, Századok, 1890, $20-43$.

${ }^{45}$ Упор. напомену бр. 43.

${ }^{46}$ A, III, 79-82; Gy. Györffy, Magyarország történeti földrajza, I, 206, 227.
} 
боравили на краљевском двору или већ дане проводили у војним походима и дипломатским мисијама у пратњи владара, а Бач им је био извор прихода. Будући да је надбискуп Ласло уједно био дугогодишњи канцелар (1317-1336) Карла Роберта, и за њега би се пре могло претпоставити да је живео и радио на краљевском двору у Вишеграду, а да му је његова Бачка дијецеза била достојна награда за одговорну службу краљевског канцелара. ${ }^{47}$

Дакле, уз напомену да је питање богате прошлости средњовековне бачке тврђаве још увек пуно непознаница и чека на нова открића, надамо се да ће овај рад бити прилог познавању њеног статуса у време владавине Карла Роберта Анжујског. По нама, Бач је 21. априла 1328. године свакако био краљевска тврђава. По свему судећи, такав статус није изгубио ни 2. новембра 1335. године, а сасвим је вероватно био краљевски и у време када су два поседа „Kethlugas“ de facto доспела у руке тадашњег бачког жупана Тамаша Сечењија (1318-1321). Од краја друге деценије XIV века (1318-1333), бачком жупанијом су управљали најближи краљеви великаши и сарадници, будући ердељски војвода Тамаш Сечењи, краљевски магистар таверника Деметер Некчеи и палатин Жан Другет. Није искључено да је већ у периоду њиховог жупанства била започета градња нове бачке тврђаве. Краљевски статус бачке тврђаве из 1328. године не искључује могућност да су Бач и његова тврђава истовремено били и резиденција калочког надбискупа.

\section{Извори и литература:}

Извори:

Anjoukori okmánytár, Codex diplomaticus Hungaricus Andegavensis, I-VII, Nagy, Imre - Tasnádi Nagy, Gyula (eds.), Budapest 1878-1920.

Ioannis Cinnami Epitome rerum ab Ioanne et Alexio Comnenis gestarum, Corpus scriptorum historiae Byzantinae, ed. A. Meineke, Bonae 1836.

Paulini, Ján, Arabské správi o Slovanoch (9.-12. storočie), Bratislava 1999.

Petri de Warda, Epistolae Cum Nonnullis Wladislai II. Regis Hungariae Literis Petri Causa Scriptis, ed. Carolus Wagner, Posonii et Cassoviae 1776.

Литература:

Алмаши, Тибор, Главне институције писмености места с јавном вером у средњем веку на тлу данашње Војводине, у: Средњовековна насеља на тлу Војводине, историјски проиеси и догађаји, уредник Ђура Харди, Сремска Митровица 2013, 29-46.

Бошковић, Ђурђе, Средњовековни градови у Војводини, архитектура, у: Војводина I, уредник Душан Ј. Поповић, Нови Сад 1939, 310-329.

\footnotetext{
${ }^{47}$ P. Engel, Magyarország világi archontológiája, I, 65, 89.
} 
Букуров, Бранислав, Насеља Војводине, у: Војводина знаменитости и лепоте, уредник Михаило Милетић, Београд 1968, 112-122.

Györffy, György, Az Árpád-kori Magyarország történeti földrajza, I, Budapest 1963.

Engel, Pál, Magyarország világi archontológiája, I-II, Budapest 1996.

Engel, Pál, Az ország újraegyesitése, I. Károly küzdelmei az oligarchák ellen (1310-1323), Századok, 1988, 89-146.

Zsoldos, Attila, Magyarország világi archontológiája 1000-1301, Budapest 2011.

Историја српског народа, група аутора, уредник Јованка Калић, друга књига, Београд 1982.

Iványi, István - (Virter, Ferencz), Bács-Bodrog vármegye községei, kiegészítette Virter Ferencz, y: Bács-Bodrog vármegye, szerk. Borovszky Samu, elektronikus kiadás, Budapest Arcanum Adatbázis Kft. 2004 (http://mek.oszk.hu/09500/09536/html/0002/6.html).

Крстић, Александар, Ковин, у: Лексикон градова и тргова средњовековних српских земаља, редактор Синиша Мишић, Београд 2010, 131-134.

Marosi, Ernő -Takákacs, Miklós, Bács, y: Korai magyar történeti lexikon (9-14. század), főszerkesztő Kristó Gyula (даље KMTL), Budapest 1994, 73-75.

Pór, Antal, Lipóczi és Nekcsei Demeter és Sándor, Századok, 1890, 20-43.

Reiszig, Ede, Bács-Bodrog vármegye története, y: Magyarország vármegyéi és városai: BácsBodrog vármegye II, szerk. Borovszky Samu, elektronikus kiadás, Budapest, Arcanum Adatbázis Kft. 2004 (http://mek.oszk.hu/09500/09536/html/0003/4.html).

Schmidt, Rudolf R., Iz prošlosti Bača, Гласник Историјског друштва у Новом Саду, 37-38 (3-4), 1939, 382-413.

Sebők, Ferenc, Szécsényi, y: KMTL, 620.

Sekulić, Ante, Drevni Bač, Split 1978.

Skalská, Monika, Tomášs zo Sečian a jeho zásluhy v bitke pri Rozhanovciach, y: Bitka pri Rozhanovciach $v$ kontexte slovenských a uhorských dejín. Zborník príspevkov z medzinárodnej vedeckej konferencie pri príležitosti 700. výročia bitky pri Rozhanovciach. Eds. Ferdinand Uličný, Drahoslav Magdoško, Košice 2012, 155-166.

Стојковски, Борис, Арапски географ Идризи о јужној Угарској и Србији, Зборник Матице српске за историју, 79-80, 2009, 59-60.

Ћирковић, Сима, Бач, у: Војводина знаменитости и лепоте, уредник Михаило Малетић, Београд 1968, 436-437.

Fraknói, Vilmos, Váradi Péter kalocsai érsek élete 1480-1511, Századok 1883, 489-514, 729-749, $852-843$.

Henszlmann, Imre, Bács, Archaeologiai Értesítő, 1870 III kötet, 309-314; IV kötet, 2-9, 24-31, 49-56, 85-93.

Hardi, Đura, Drugeti, povest o usponu i padu porodice pratilaca Anžujskih kraljeva, Novi Sad 2012.

Харди,Һура, Петроварадин - „престоница“ једног Анжујча, у: Средњовековна насеља на тлу Војводине, историјски проиеси и догађаји, уредник Ђура Харди, Сремска Митровица 2013, 243-279.

Csánki, Dezső, Magyarország történelmi földrajza a Hunyadiak korában, I-III, Budapest 1890-1913.

Шмит, Рудолф Р., Средњовековни градови у Војводини, историја, у: Војводина I, уредник Душан Ј. Поповић, Нови Сад 1939, 301-310. 


\title{
„CASTRUM REGIS BACHIENSIS” ANNO 1328 OR ONE CONTRIBUTION TO THE QUESTION OF STATUS OF BAČ FORTRESS
}

\begin{abstract}
Summary
In this paper the author attempted to give a contribution to the question of ownership over Bač fortress in the middle of the first half of the $14^{\text {th }}$ century. Due to its strategic importance on the Danubian route and border, Bač was one of the most important fortifications in Southern Pannonia since the early Middle Ages. There is a well established view in historiography that Bač along with its fortress belonged to the Episcope of Bač, and thus to the archbishop of Kalocsa-Bač. Still, due to the lack of sources and the longevity of the period (12th -16 th cent.), the question of the status of Bač fortress is very complex. The author draws attention to the fact that according to a charter issued on April 21, 1328, that is its rescript of November 2, 1335, Hungarian ruler Charles Robert of Anjou (1301-1342) spoke of Bač as his fortress. The document in question is a donation which the ruler issued to the Duke of Transylvania Tamás Széchenyi in relation to two landholdings "Kethlugas" in Bač County. The first of the donated properties was - "the land of our (royal) Bač fortress" (unam terram castri nostri Bachiensis), while the other "(Keth)lugas" was a vacant property of a certain Peter, a professional participant in court duels, who died without (male) heirs. Tamás Széchenyi de facto acquired these two properties earlier, that is at the time when he was the county prefect of Bač (1318-1321), which can be connected to the assumption that Bač was even then a royal property. The status of a royal fortress Bač did not only hold in 1328, but probably in 1335, as well as between 1318 and 1321. That was the time during which the imposing Bač fortress was built by a French or some other western architectural model, commissioned by Charles Robert, as once stated by Imre Henszlmann. Since the second decade of the $14^{\text {th }}$ century the District of Bač was governed by magnates and associates closest to the King, such as the future Transylvanian duke Tamás Széchenyi, royal magistrate of innkeepers Demeter Nekczei and palatine Jean Drugeth. It has not been excluded that during their mandate the building of new Bač fortress had been initiated. The royal status of Bač fortress in 1328 does not rule out the possibility that Bač and its fortress were simultaneously the residence of another King's baron, his chancellor, the archbishop of Kalocsa.
\end{abstract}

Keywords: Bač, Bač Fortress, Charles Robert of Anjou (1301-1342), Bačka in the $14^{\text {th }}$ century. 